\title{
Physico-chemical Properties and Consumer Acceptability of Mango Herbal Quarg Type Cheese
}

\author{
Dhiraj H. Kankhare, Vishal P. Patil, Sachin P. Ramteke* and Somnath H. Mane \\ Department of Animal Husbandry and Dairy Science, Mahatma Phule Krishi Vidyapeeth, \\ Rahuri (M.H.) - 413722, India \\ *Corresponding author
}

\begin{abstract}
\begin{tabular}{l} 
Ke y w o r d s \\
Quarg type cheese, \\
Herbal, Mango \\
pulp, Spices, \\
Cardamom, Clove \\
\hline Article Info \\
$\begin{array}{l}\text { Accepted: } \\
10 \text { November } 2019 \\
\text { Available Online: } \\
10 \text { December } 2019\end{array}$ \\
\hline
\end{tabular}
A B S T R A C T

The present study was undertaken with the objective to know the consumer acceptability and physico-chemical qualities of mango herbal quarg cheese. The mango herbal quarg type cheese was prepared by adding different levels of mango pulp, cardamom and clove. The products were evaluated for physico-chemical qualities and consumer acceptability. The chemical composition of most acceptable treatment $\left(\mathrm{T}_{2}\right)$ was 9.04, 11.19, 4.24, 1.40, 25.82, 74.18, 4.58 and 1.01 per cent fat, protein, carbohydrate, ash, total solids, moisture, $\mathrm{pH}$ and acidity respectively. The quarg type cheese prepared with $(27$ per cent mango pulp +0.6 per cent cardamom +0.4 per cent clove) i.e. $\mathrm{T}_{2}$ was responded by consumers as 12 per cent excellent, 60 per cent as very good and 28.00 per cent as fair about quality of mango herbal quarg type cheese.
\end{abstract}

\section{Introduction}

India stands number one position in milk production of 165.4 million MT/ annum in 2016-17 (Anonymous, 2017). Dairy farmers can add value to their milk by processing and marketing their own products, such as cheese, yogurt, butter, ice cream, and farm-bottled milk. Many consumers are willing to pay a premium for locally produced, high-quality, farmstead dairy products and may further enhance the market potential. A trend has been observed amongst customers towards minimally processed, highly nutritious, health promoting and flavour enriched food (Mitra and Ghosh, 2017). Fermentation is the oldest and most economical method in food preservation and value addition to milk. Fermented milk provides all the milk components modified through the process of fermentation by lactic acid bacteria. The conversion of part of lactose to lactic acid during fermentation, destabilize the casein by lowering the $\mathrm{pH}$ and their by enhance the 
digestibility (Pinto et al., 2007). Numbers of fermented dairy products are being prepared all over the world including dahi, yoghurt, lassi, cultured butter milk, acidophilus milk, kefir, and cheese.

The major cheese production has centred in western countries (Singh, 2011). Cheese is held in high esteem in the food system and in food chain owing to its excellent portability, long life and good nutritive value (Bhongale $e t$ al., 2016). The most popular variety of cheese is cheddar, mozzarella, feta, cottage and quarg cheese. Quarg is a natural, unripened, fresh cheese produced on a large scale in Germany. It is essentially a milk protein and fat, manufactured by acid coagulation of milk by bacterial cultures (e.g. Steptococcus cremoris and Leuconostoc citrovorum) with small rennet addition for better separation of the protein coagulum from the whey and thus better yields. It is produced in a variety of fat contents, ranging from an essentially fat free type to a variant with as much as 40 per cent fat in the dry matter. Quarg is generally used as spread and often used as an ingredient for sandwiches, salads, cheese cake in Germany. It has a typical slightly sweet (unlike sour cream) flavour and taste which is not generally accepted by the Indians. Indian likes slightly spicy, salty, sour and astringent flavour. It is common practice of using fruits in preparation of various dairy products like ice-cream, yoghurt and Shrikhand. Keeping in view of the market trends, incorporation of fruits in traditional fermented milk products not only aids in value addition and product diversification but also helps in checking the post-harvest losses and hence economic losses. Fruits are rich source of various important phytonutrients namely, vitamins, minerals, antioxidants and dietary fibers (Kanawjia et al., 2011). Mango (Mangifera indica $L$.) is commercially the most important fruit crop of India. It is known for its strong aroma, intense peel coloration, delicious taste, and high nutritive value due to its high content of vitamin $\mathrm{C}, \beta$-carotene and minerals. The flavour and palatability of most of the food is increased by the spices. The spices are used in comparatively small quantities in the food products. Most of the Indian spices have antiinflammatory, antioxidant, antibacterial, anticancer, anti-carcinogenic properties. Cardamom and clove are most common spices traditionally used in Indian culinary dishes. Considering the nutritional importance of mango and use of cardamom and clove in traditional dishes or spread, mango herbal quarge type cheese has been prepared by incorporating them.

\section{Materials and Methods}

Fresh cow milk was procured from ResearchCum Development Project on cattle, located at central campus, M.P.K.V., Rahuri. LF-40 starter culture was procured from Division of Dairy Microbiology, N.D.R.I., Karnal (India). Microbial "Meito" rennet was purchased from CHR HANSEN Ltd. Mumbai. Jain Farm fresh Alphanso variety mango pulp was procured from Ahmednagar. Cardamom powder, Clove powder was purchased from local market. The muslin cloth of $1 \times 1 \mathrm{~m}$ size (90 mesh) was used for draining of whey.

\section{Preparation of mango herbal quarg type cheese}

The quarg type cheese was prepared by using technology developed at NDRI for manufacturing of quarg cheese, prescribed by Gahane (2008) with some minor modifications (Fig. 1).

\section{Treatment detail}

Pre-experimental trials were conducted and on the basis of the results of sensory evaluation the final experimental trials were as follows, $\mathrm{T}_{0}$ (control), $\mathrm{T}_{1}$ - Mango pulp 27\%, $\mathrm{T}_{2}$ - 
Mango pulp $27 \%+$ Cardamom powder $0.6 \%$ + Clove powder $0.4 \%, \mathrm{~T}_{3}-$ Mango pulp $27 \%+$ Cardamom powder $0.6 \%+$ Clove powder $0.5 \%, \mathrm{~T}_{4}-$ Mango pulp $27 \%+$ Cardamom powder $0.7 \%+$ Clove powder $0.4 \%, \mathrm{~T}_{5}-$ Mango pulp $27 \%$ + Cardamom powder $0.7 \%$ + Clove powder $0.5 \%$.

\section{Consumer acceptability}

The sample of selected treatment $\mathrm{T}_{2}(27 \%$ mango pulp $+0.6 \%$ cardamom $+0.4 \%$ clove) was prepared and offered to the consumers. The test was carried out with 50 respondents in local area categorized as per age, occupation, education and gender. The product was served and asked to indicate their liking about the product.

\section{Analytical methods}

\section{Chemical analysis}

Fat percentage of quarg type cheese was determined by method described in IS: 1224 (part II)-1977. For the determination of protein, total nitrogen was determined by Micro-Kjeldhal method described in A.O.A.C. 1995. The percent protein was obtained by multiplying total nitrogen by 6.38 . The total carbohydrate content of cheese was calculated by difference to achieve $100 \%$ of total contents. The total solid percentage in quarg type cheese was determined by using gravimetric method as described in IS: 1479 (part II)-1961. Moisture content in quarg type cheese sample was calculated by deducting percentage of total solid content from 100. Ash of the quarg type cheese was determined by method given in IS: SP: 18, Part XI (1981). The acidity of quarg type cheese was determined as per the method given in IS: 1479 (part I) -1960. The $\mathrm{pH}$ of quarg type cheese was determined using microprocessor controlled $\mathrm{pH}$ meter (Labindia, New Delhi) combined with glass electrode.

\section{Statistical analysis}

The data obtained from trials of final treatment replicated three times was analyzed by Completely Randomized Design (CRD) method (Snedecor and Cochran, 1994). The data obtained from consumer profile was analyzed by Chi-square test.

\section{Results and Discussion}

\section{Physico-chemical properties of mango herbal quarg type cheese}

\section{Fat}

The fat content in mango herbal quarg type cheese was significantly decreased as compared to control. The mean fat ranged between $T_{0}(10.72)$ to $T_{5}(9.05)$. Fat significantly decreased due to the low fat content in fruit pulp as compared to milk. Similar results were observed by Deshpande et al., (2005) reported that with increasing the level of mango pulp for preparation of Amrakhand there was decrease in fat content of product. Nigam et al., (2009) reported that fat content of papaya pulp shrikhand also observed that decreasing fat with increasing level of papaya pulp. It was observed slight increase in fat from $T_{2}$ to $T_{5}$ due to addition of spices. Similar results were observed by Hamid and Abdelrahman (2012) on addition of cardamom powder in white cheese prepared from goat milk. The same trend of increase in fat on addition of cardamom and clove powder in paneer was reported by Eresam et al., (2013) in his work of evaluating spices in extending shelf life of paneer.

\section{Protein}

It is revealed from the results presented in Table 1 that the protein content in mango herbal quarg type cheese was ranged between 11.18 to 11.61 per cent. It was significantly 
decreased as compared to control. This might be attributed to the low protein content in fruit pulp as compared to milk.

These results obtained are similar with the work of Desai et al., (1994) in the work of utilization of mango pulp in yogurt. The data in Table 1 indicates slight increase in protein was observed from $T_{2}$ to $T_{5}$ due to addition of spices.

Similar results were found by Hamid and Abdelrahman (2012) on addition of cardamom powder in white cheese prepared from goat milk. The mean values for chemical composition of controlled sample $\left(\mathrm{T}_{0}\right)$ are in close agreement with Gahane (2008) and Kadiya (2009).

\section{Total carbohydrate}

Total carbohydrate of mango herbal quarg cheese significantly increased from 4.04 to 4.29 with the admixing of mango pulp and spices in quarg type cheese. The present results are similar to Biswas et al., (2017) he observed mango juice contained dahi had higher amount of carbohydrate than control dahi. Results in Table 1 illustrate slight increase in carbohydrate from $T_{2}$ to $T_{5}$ due to addition of spices.

\section{Total solid}

Total solid of mango herbal quarg cheese significantly decreased due to addition of mango pulp and spices. It had been observed slight increase in total solids was observed from $T_{2}$ to $T_{5}$ due to addition of cardamom and clove spice powder. The similar trend was reported by Bose (1985) due to higher moisture $(78-82 \%)$ in mango pulp.

\section{Moisture}

Moisture content from $\mathrm{T}_{0}$ to $\mathrm{T}_{5}$ varied between the ranges of 72.20 to 74.18 . The moisture content of mango herbal quarg cheese significantly increased due to addition of mango pulp and spices. These might be due to due to high moisture content in mango pulp as compared to cheese. Slight decrease in moisture was revealed in Table 1 from $T_{2}$ to $\mathrm{T}_{5}$ due to addition of spices.

Similar results were found by Hamid and Abdelrahman (2012) on addition of cardamom powder in white cheese prepared from goat milk.

Ash

The mango herbal quarg type cheese showed non-significant effect on ash content from $\mathrm{T}_{0}$ to $\mathrm{T}_{5}$ varied between the range of 1.39 to 1.41 , on Addition of mango pulp decreased the ash content in $\left(\mathrm{T}_{1}\right)$ was observed as compared to control quarg type cheese and from ( $T_{2}$ to $\left.T_{5}\right)$ on addition of spices the ash content slightly increased in mango herbal quarg type cheese.

\section{Acidity}

The perusal of data reveals that the acidity of mango herbal quarg cheese significantly increased from 0.9 to 1.03 due to addition of increasing level of mango pulp and spices.

These finding agrees with the work of Desai et al., (1994) who found that titratable acidity of fruit yogurt was significantly increased due to addition of fruit pulp/ juices.

Present findings of acidity of mango herbal quarg cheese are found similar with the results found by Raut et al., (2015), Biswas et al., (2017). Slight increase in acidiy on addition of clove powder was reported by Eresam et al., (2013) in his work of evaluating spices in extending shelf life of paneer. The perusal data for chemical composition of controlled sample $\left(\mathrm{T}_{0}\right)$ are in close agreement with Gahane (2008) and Kadiya (2009). 
Table.1 Physico-chemical properties of mango herbal quarg type cheese

\begin{tabular}{|c|c|c|c|c|c|c|c|c|}
\hline $\begin{array}{c}\text { Treatmen } \\
\mathbf{t}\end{array}$ & $\begin{array}{l}\text { Fat } \\
(\%)\end{array}$ & $\begin{array}{c}\text { Protein } \\
(\%)\end{array}$ & $\begin{array}{c}\text { Carbo- } \\
\text { hydrate } \\
(\%)\end{array}$ & $\begin{array}{l}\text { T.S. } \\
(\%)\end{array}$ & $\begin{array}{c}\text { Moisture } \\
(\%)\end{array}$ & $\operatorname{Ash}(\%)$ & $\begin{array}{c}\text { Acidity } \\
(\%)\end{array}$ & pH \\
\hline $\mathbf{T}_{\mathbf{0}}$ & $10.72^{\mathrm{a}}$ & $11.61^{\mathrm{a}}$ & $4.04^{d}$ & $27.78^{\mathrm{a}}$ & $72.22^{c}$ & 1.41 & $0.91^{d}$ & $4.67^{\mathrm{a}}$ \\
\hline $\mathbf{T}_{1}$ & $9.02^{c}$ & $11.18^{c}$ & $4.21^{c}$ & $25.80^{c}$ & $74.20^{\mathrm{a}}$ & 1.39 & $1.00^{\mathrm{c}}$ & $4.59^{b}$ \\
\hline $\mathbf{T}_{2}$ & $9.04^{b c}$ & $11.19^{b c}$ & $4.24^{b c}$ & $25.82^{b c}$ & $74.18^{\mathrm{ab}}$ & 1.40 & $1.01^{b c}$ & $4.58^{b c}$ \\
\hline $\mathbf{T}_{3}$ & $9.04^{b c}$ & $11.19^{b c}$ & $4.25^{b}$ & $25.82^{b c}$ & $74.18^{\mathrm{ab}}$ & 1.40 & $1.02^{\mathrm{ab}}$ & $4.58^{b c}$ \\
\hline $\mathbf{T}_{4}$ & $9.05^{b c}$ & $11.20^{\mathrm{bc}}$ & $4.28^{\mathrm{a}}$ & $25.83^{b}$ & $74.17^{b}$ & 1.41 & $1.02^{\mathrm{ab}}$ & $4.57^{\mathrm{c}}$ \\
\hline $\mathbf{T}_{5}$ & $9.05^{b}$ & $11.20^{\mathrm{b}}$ & $4.29^{\mathrm{a}}$ & $25.83^{b}$ & $74.17^{b}$ & 1.41 & $1.03^{\mathrm{a}}$ & $4.57^{\mathrm{c}}$ \\
\hline S.E. \pm & 0.011 & 0.008 & 0.01 & 0.01 & 0.01 & 0.008 & 0.006 & 0.005 \\
\hline $\begin{array}{c}\text { C.D.@ } \\
5 \%\end{array}$ & 0.034 & 0.02 & 0.03 & 0.03 & 0.03 & - & 0.01 & 0.01 \\
\hline
\end{tabular}

Values with different superscript differ significantly $(\mathrm{P}<0.05)$

Table.2 Effect of independents on acceptability of quarg type cheese

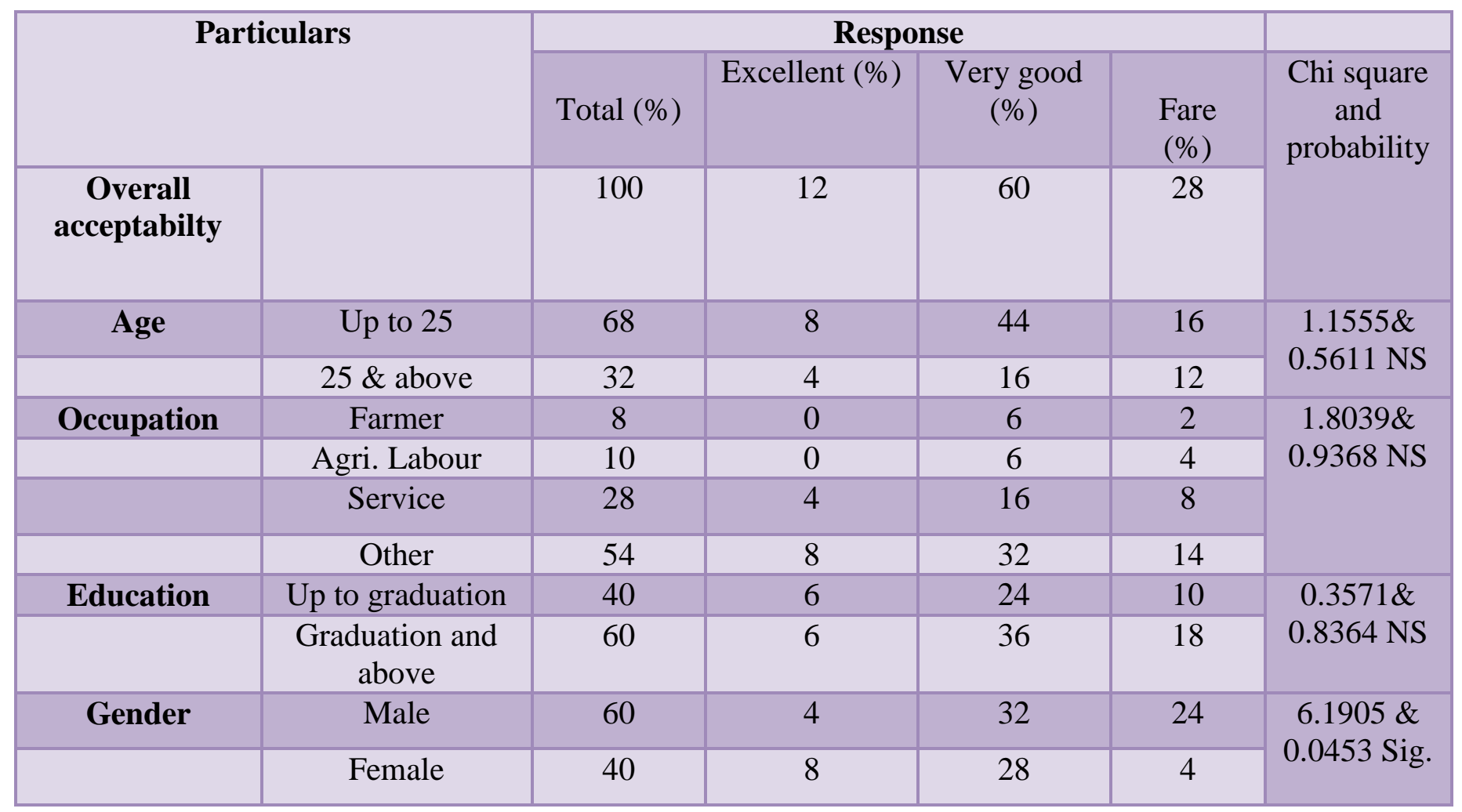


Fig.1 Flow chart for manufacture of mango herbal quarg type cheese

Fresh Cow milk

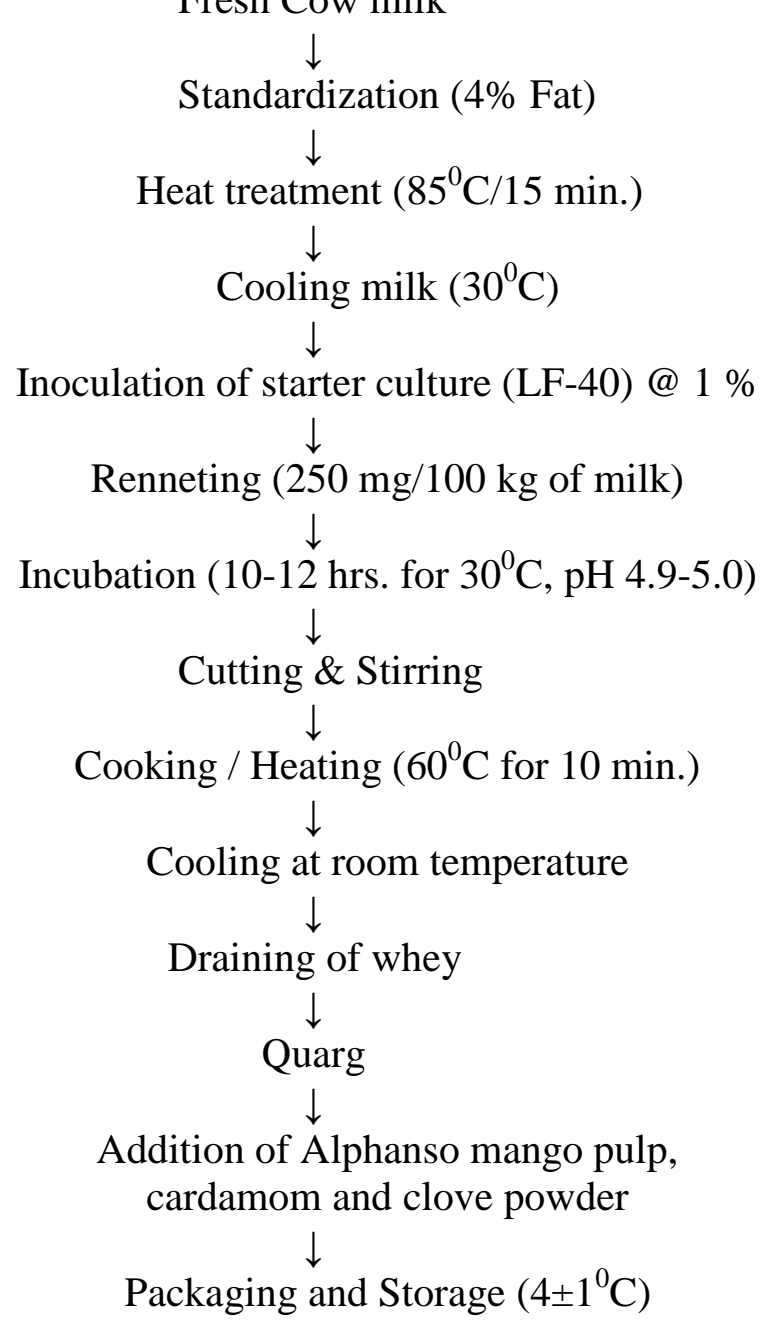

pH

The mean value of $\mathrm{pH}$ content of treatments $\mathrm{T}_{0}$ to $\mathrm{T}_{5}$ were 4.67 to 4.57 respectively. $\mathrm{pH}$ of mango herbal quarg cheese significantly decreased due to addition of mango pulp and spices.

\section{Consumer acceptability of mango herbal quarg type cheese}

The efforts were made to know the consumer acceptance in term of their age, occupation, education and gender. It was evidenced that the 68 per cent consumers were below 25 year age and the remaining 32 per cent above 25 year. Considering the occupation of the consumers, it was observed that 54 per cent were other occupational persons (mainly students) followed by service (28\%), agricultural labour (10\%) and farmers $(8 \%)$. The educational qualification of 60 per cent consumers was above graduation and remaining 40 per cent below graduation. Out of the total consumers, 60 per cent were male and 40 were females.

\section{Effect of independents on acceptability of quarg type cheese}

The effect within the class of age, occupation, education and gender were analyzed 
statistically by adopting $\lambda 2$ test. It was noticed that 12 per cent consumers reported the product as excellent, 60 per cent as very good and 28.00 per cent as fair about quality of quarg type cheese. From the Table 2, it was found that the perceptiveness of consumers liking influenced statistically significant due to gender only and occupation, education and age did not play any role in case of quarg type cheese.

The proximate composition of the product include $9.04 \%$ fat, $11.19 \%$ protein, $4.24 \%$ total carbohydrate, $25.82 \%$ total solids, $74.18 \%$ moisture, $1.40 \%$ ash, $1.01 \%$ acidity and $4.54 \mathrm{pH}$. The perceptiveness of consumers liking influenced statistically significant due to gender only and occupation, education and age did not play any role in case of mango herbal quarg type cheese. In overall acceptance $60 \%$ consumers rated the product very good. Thus it could be concluded that mango pulp and spices (cardamom and clove) used in combination for preparation of quarg type cheese was acceptable.

\section{Acknowledgment}

The authors are thankful to department of animal husbandry and dairy science, PGI, MPKV, Rahuri for their support all though.

\section{References}

A.O.A.C. (1995).Official methods of analysis, 16th Edition. Association of Official Analytical Chemists, Washington, D.C., U.S.A.

Anonymous (2017). Annual Report 2016-17, Dept. of Animal Husb., Dairy Sci. and Fishery, Govt. of India.

Bhongle, P., Sabikhi, L., and MH, S. K. 2016. An optimized process of Indian farmstead artisanal cheese: Value addition for increased farm income. Indian Journal of Dairy Science,
69(3): 252-258.

Biswas, S.R., Kibriya.S., Habib, R.M., (2017) Preparation of dahi from cow and buffalo skim milk with addition of mango (Mangifera indica) juice. Asian J. Med. Biol. Res.3 (2): 191-197.

Bose, T.K. (1985). Tropical and subtropical fruits, Maya prakashan, 206, BidhanSarani, Culcutta, pp 304-315.

Desai, S.R., Toro, V.A. and Joshi, S.V. (1994).Utilization of different fruit pulp in manufacture of yoghurt. Indian J. Dairy Sci., 47(10): 870- 874.

Deshpande, S., Jha Krishna and Bargale, P.C. (2005) Quality and acceptability of soy milk based Amrakhand. J. Dairying, Foods and H.S., 24(1): 16-19.

Eresam, K.K., Pinto S., Aparnathi, K.D. (2015) Evaluation of selected spices in extending shelf life of paneer. J. Food Sci. Technol, 52 (4): 2043-2052.

Gahane, H.B. (2008). Development of Quarg type cheese with enriched functional attributes from buffalo milk. Thesis submitted to National Dairy Research Institute, Karnal (Haryana).

Hamid O.A., and Abdelrahman N.A. (2012) Effect of adding cardamom, cinnamon and fenugreek to goat's milk curd on quality of white cheese during storage. International J. of Dairy Science, 7 (2): 43-50.

IS:1224 part II (1977). Determination of fat by Gerber's method (revised) Indian Standards institution, Manak Bhavan, New Delhi.

IS:1479 Part-I (1960). Methods for test for Dairy industry, chemical analysis of milk. Indian standard Institution, Manak Bhavan, New Delhi.

IS:SP 18, part XI (1981). Hand book of food analysis, part XI., Dairy Products. Bureau of Indian Standards, Manak Bhavan, New Delhi.

Kadiya, K.S. (2009). Development of functional Quarg cheese with extended 
shelf life. Thesis submitted to National Dairy Research Institute, Karnal, Haryana.

Kanawjia, S.K., Kadiya K., Khetra Y and Chatterjee A. (2011). Development in Quarg cheese technology. Centre of Advanced Faculty Training Compendium on Technological development in cheese and fermented dairy foods. NRDI, Karnal 2011: 4047.

Mitra, S. and Ghosh, B. C. (2017) Kefir- an alternative fermented milk, Indian Dairyman:: 78-81.

Nigam, N.R., Singh and P.K. Upadhayay 2009. Incorporation of chakka by papaya pulp in the manufacture of shrikhand. J. Dairying. Foods and H.S. 28 (2): 115-118.

Pinto, S., Rathour, A. K., Prajapati, J. P., Jana, A. H., and Solanky, M. J. 2007. Utilization of whey protein concentrate in processed cheese spread. Natural Product Radiance, 6(7): 398-401.

Raut, V., Sawant, P., Sawant, D., and Ingole A. S., (2015) Studies on preparation of mango yogurt drink. Asian J. Dairy and Food Res., 34 (1):13-17.

Snedecor, G. W. and Cochran, W. G. (1994).Statistical method. First EastWest Press Edition. Eight Ed. pp 297301.

\section{How to cite this article:}

Dhiraj H. Kankhare, Vishal P. Patil, Sachin P. Ramteke and Somnath H. Mane. 2019. Physicochemical Properties and Consumer Acceptability of Mango Herbal Quarg Type Cheese. Int.J.Curr.Microbiol.App.Sci. 8(12): 1082-1089. doi: https://doi.org/10.20546/ijcmas.2019.812.137 